\title{
A Case of Intestinal Obstruction Caused by Gossypiboma Recognized 9 Years Later
}

\section{Dokuz Yıl Sonra Fark Edilen Gossipibomanın Neden Olduğu Bir Barsak Tıkanıklığı Olgusu}

\author{
(1) Tolga Kalaycı \\ Erzurum Regional Training and Research Hospital, Clinic of General Surgery, Erzurum, Turkey
}

\begin{abstract}
HIIIIII| ABSTRACT
The term gossypiboma is used to describe a retained surgical sponge after operation. It is a rare but serious complication which is seldom reported because of the medicolegal implications. Gossypiboma can even remain silent and present years after the operation. We report a case of a 38-year-old lady who presented with abdominal pain, nausea, vomiting and absence of defecation for three days. She had a history of cesarean section 9 years ago. At tomography, a encapsulated, well-organised, calcified solid mass was seen in the middle of abdominal cavity. A diagnostic laparotomy was planned. On exploration, it was observed that there was a large gossypiboma attached to the small intestine and surrounding structures. Though rare, gossypiboma should be kept in mind as a differential diagnosis in postoperative cases presenting as abdominal pain and symptoms of intestinal obstruction even years after the operation.
\end{abstract}

Keywords: Complication, gossypiboma, intestinal obstruction

\section{|IIIIIII| ÖZ}

Gossipiboma terimi, ameliyattan sonra kalan cerrahi materyali tanımlamak için kullanılır. Medikolegal problemler nedeniyle bildirimi nadir yapılan, nadir ve ciddi bir komplikasyondur. Gossipiboma sessiz kalabilir ve operasyondan yıllar sonra ortaya çıkabilir. Bu olgu sunumunda; karın ağrısı, bulantı, kusma ve üç gündür dışkılama yokluğu ile başvuran 38 yaşında bir bayan olgusunu sunmaktayız. Hastanın sadece 9 yıl önce sezaryen öyküsü vardı. Tomografide karın boşluğunun ortasında kapsüllenmiş, iyi organize olmuş, kalsifiye solid kitle görüldü. Tanısal laparotomi planlandı. Eksplorasyonda ince barsak ve çevresindeki yapılara yapışık büyük bir gossipiboma olduğu görüldü. Ameliyattan yıllar sonra karın ağrısı ve barsak tıkanıklığı semptomları ile ortaya çıkan postoperatif olgularda nadir de olsa gossipiboma ayırıcı tanı olarak akılda tutulmalıdır.

Anahtar Kelimeler: Komplikasyon, gossipiboma, intestinal obstrüksiyon

\section{Introduction}

Gossypiboma is a surgical sponge left behind in the surgical area after surgical plan integrity is achieved. ${ }^{1}$ It is an unexpected unlikely complication. Because clinical findings of gossypibomas largely vary, diagnosis can be difficult. Because of this variability, gossypibomas can cause serious morbidity in patients.

While most gossypiboma cases are detected in the early postoperative period, some cases may go unnoticed for years. ${ }^{2}$
Imaging methods can help make a definitive diagnosis. In these cases, the recommended treatment option is surgery. Gossypiboma can be considered a prediagnosis in patients with a previous surgical history and an intra-abdominal mass. This paper presents a case of intestinal obstruction caused by a gossypiboma.

\section{Case Report}

A 38-year-old female patient was admitted to the emergency clinic with complaints of intensifying abdominal pain,

Address for Correspondence/Yazışma Adresi: Tolga Kalaycı, MD, 
nausea, vomiting and absence of defecation for 3 days. The patient vomited three times daily and without blood, and the vomitus contained food. She had undergone caesarean section at another hospital 9 years ago. Within 9 years, she had intermittent constipation. She received medical treatment for the constipation. Until this stage, no further investigation was made. Thus, definitive diagnosis was not made, and her treatment was arranged.

On physical examination, she had respiratory rate of 28 breaths/minute, blood pressure of 105/55 mmHg and heart rate of 117 beats/minute. Physical examination was remarkable for abdominal distension, diffuse tenderness and decreased bowel sounds. Subfebrile temperature (37.8 ${ }^{\circ} \mathrm{C}$ ) was reported. The patient had a septic appearance.

Laboratory tests revealed a white blood cell count of 13,800/ $\mathrm{mm}^{3}$ and a red blood cell count of $3.2 \times 106 \mathrm{~mm}^{3}$. The haemoglobin level was $11.8 \mathrm{~g} / \mathrm{dL}$, and C-reactive protein level was 27 (0-5) $\mathrm{mg} / \mathrm{L}$.

Because of septic clinical appearance, contrast-enhanced computed tomography (CT) of the abdominopelvic cavity was performed. An encapsulated, well-organised, calcified $73 \times 49 \times 47 \mathrm{~mm}^{3}$ size solid mass was seen in the middle part of the abdominal cavity. Proximal small intestine segments were enlarged because of the mass. Presumably, both bowel and colon segments adhered to the mass (Figure 1).

The patient was taken for emergency explorative laparotomy. During surgery, the mass was actually tense and encapsulated, measuring $80 \times 50 \times 50 \mathrm{~mm}^{3}$ in size, and densely adhered to the surrounding small bowel, right colonic segment and omentum. The mass was open partially during dissection, revealing thick pus and a retained sponge (Figure 2, 3). During dissection, the full thickness of the jejunal segment was opened, which was repaired with partial resection and double-layer anastomosis. Moreover, ileal and right colonic serosal injuries occurred, and one-layer

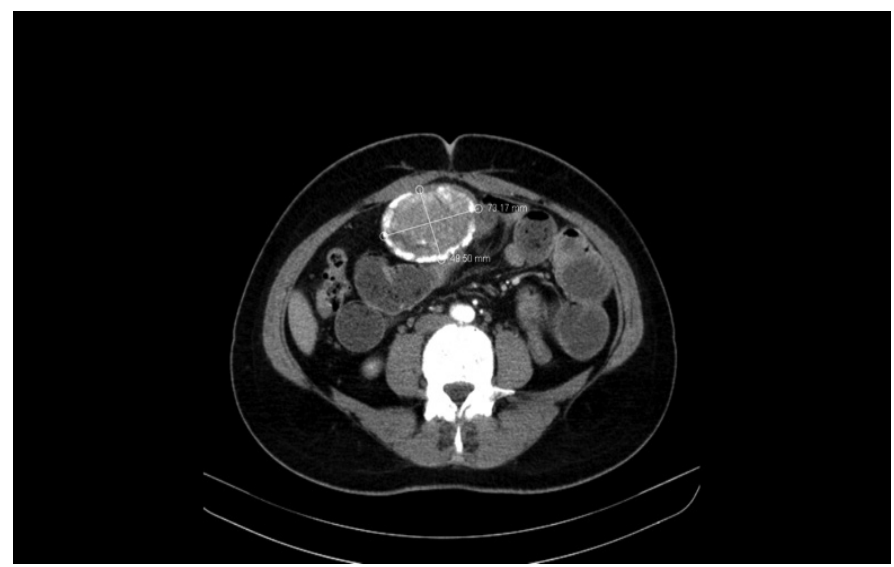

Figure 1. Intra-abdominal computed tomography image of a gossypiboma repair was performed. Two drainage catheters were placed in the abdominal cavity: one in front of the anastomosis and the other in the pelvic cavity. The catheter adjacent to the anastomosis was removed on postoperative day 5 , and the other catheter was removed on postoperative day 7. The postoperative period was uneventful. The patient was discharged on postoperative day 7 . On postoperative day 20 , the patient was admitted to the emergency clinic. After evaluation, the patient was diagnosed with intestinal obstruction and was then hospitalised. After 2 days followup with medication, the patient was discharged without any problem.

\section{Discussion}

In 1884, Wilson first used the term gossypiboma to describe a surgical sponge left in the surgical area. Gossypiboma

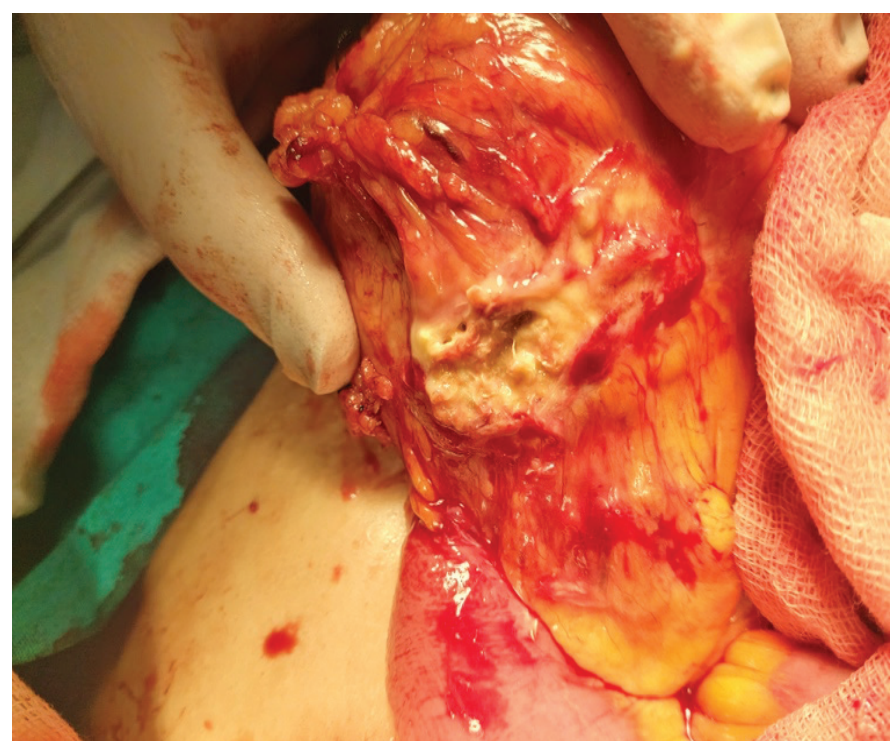

Figure 2. Intraoperative image of the gossypiboma before dissection

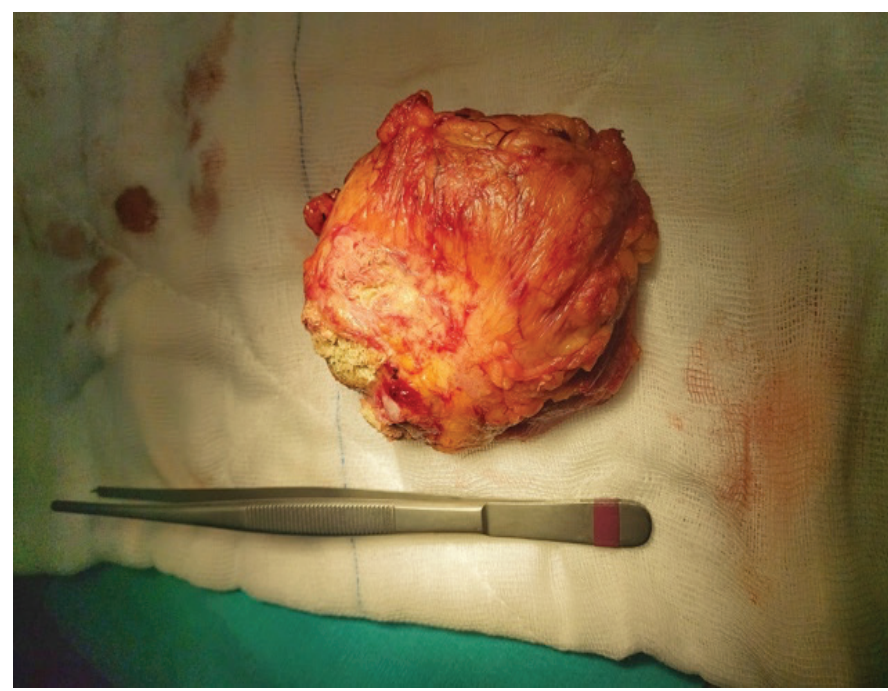

Figure 3. Intraoperative image of the gossypiboma after dissection 
occurs in $0.01 \%-0.001 \%$ of surgeries. ${ }^{3}$ The most important criterion in the diagnosis is the surgical history of the patient.

According to Durmaz et al. ${ }^{4}$, gossypiboma is especially seen after abdominopelvic surgeries. However, it can be also seen after urologic, orthopaedic, thoracic and neurosurgical surgeries. It can occur in various clinical conditions, such as acute abdomen, nausea, vomiting, tenesmus or diarrhoea, gastrointestinal tract bleeding ${ }^{5}$, intestinal obstruction ${ }^{6}$, gastric outlet obstruction ${ }^{7}$, visceral perforation, or abscess. It can be also found intraluminally because of migration. ${ }^{8}$ It can pass into internal organs and cause many types of fistula, such as organ-to-organ fistula or organ-to-cutaneous tissue fistula. ${ }^{9}$ Weight loss may be a clinical symptom in prolonged cases.

Radiological imaging can provide valuable information. The curved or banded radiopaque lines on plain X-ray imaging can be helpful. By contrast, CT should be preferred for definitive diagnosis. CT reveals a rounded mass with a dense central part and an enhancing wall or gas bubbles or deposition of calcifications. In some cases, CT reveals gossypiboma mimicking liver hydatid cyst or a subhepatic or suprahepatic cystic mass. On magnetic resonance imaging, gossypibomas may appear as low-signal-intensity lesions on T2-weighed images with wavy, stripped, or spotted appearances. ${ }^{10}$

After diagnosis of gossypiboma, treatment of all cases is surgical. On exploration of the abdomen, the foreign body may not be visible directly, because surgical tampons can be surrounded by omentum and intestines. Visceral organ necrosis and fistulas can be detected because of chronic compression and inflammation. Surgical intervention includes resection anastomoses and mass resections according to the type of gossypibomas.

In all surgical cases, surgical sponges should be counted truely. Especially, in open surgeries, marked sponges should be used if possible. Small sponges should not be used unless necessary. Nurses should be warned to count surgical sponges during surgery. Before closing the incision, the surgeon must ensure that all used surgical sponges are counted. Surgical fields should be checked again and again carefully in suspicious cases. Moreover, marked surgical sponges should be checked with radiography at the operating room. This case implies that all operating room staff should exercise maximum care to prevent this complication.

\section{Ethics}

Informed Consent: Obtained.

Peer-review: Externally and internally peer reviewed.

Financial Disclosure: The author declared that this study received no financial support.

\section{References}

1. Rajput A, Loud PA, Gibbs JF, Kraybill WG. Diagnostic challenges in patients with tumors: case 1. Gossypiboma (foreign body) manifesting 30 years after laparotomy. J Clin Oncol 2003;21:3700-3701.

2. Colak T, Olmez T, Turkmenoglu O, Dag A. Small bowel perforation due to gossypiboma caused acute abdomen. Case Rep Surg 2013;2013:219354. doi: 10.1155/2013/219354

3. Sümer A, Carparlar MA, Uslukaya O, Bayrak V, Kotan C, Kemik O, Iliklerden U. Gossypiboma: retained surgical sponge after a gynecologic procedure. Case reports in medicine 2010;2010:917626. doi: $10.1155 / 2010 / 917626$

4. Durmaz DY, Yilmaz BK, Yildiz O, Bas Y. A rare cause of chronic cough: intrathoracic gossypiboma. Iran J Radiol 2014;11:e13933. doi: 10.5812/ iranjradiol.13933

5. Erdil A, Kilciler G, Ates Y, Tuzun A, Gulsen M, Karaeren N, Dagalp K. Transgastric migration of retained intraabdominal surgical sponge: gossypiboma in the bulbus. Intern Med 2008;47:613-615.

6. Singhal BM, Kumar V, Kaval S, Singh CP. Spontaneous intraluminal migration of gossypiboma with intestinal obstruction. OA Case Reports 2013;2:145

7. Mostafa HA, Elsani A. Retained sponge after open cholecystectomy causing gastric outlet obstruction: case report and literature review. The Internet Journal of Surgery 2013;30

8. Lv YX, Yu CC, Tung CF, Wu CC. Intractable duodenal ulcer caused by transmural migration of gossypiboma into the duodenum-a case report and literature review. BMC Surg 2014;14:36,

9. Kansakar R, Thapa P, Adhikari S. Intraluminal migration of Gossypiboma without intestinal obstruction for fourteen years. J Nepal Med Assoc 2008:47:136-138

10. Manzella A, Filho PB, Albuquerque E, Farias F, Kaercher J. Imaging of gossypibomas: pictorial review. AJR Am. J. Roentgenol 2009;193:94-101. 